\title{
Pembelajaran jarak jauh during covid 19 pandemic in Indonesia and development sustainable
}

\author{
Ike Iswary Lawanda ${ }^{1^{*}}$ \\ ${ }^{1}$ Department of Library Science and Information Faculty of Humanities Universitas Indonesia.
}

\begin{abstract}
Distance learning (Pembelajaran Jarak Jauh) during pandemic Covid-19 in Indonesia indicating the image of the ideal is a way to culturally resilient adaptation. Students from primary school until higher education includes adults and institutions identify problems on infrastructure and behavior that show conscience as cultural resilience. The methodology of constructivism using method of interpretation of documentation and interview become data for the research paper. Informants of three students, parents and a teacher of music class Matahari primary school selected whom having the experience of distance learning are to interpret conscience. The distance learning to students appeals to have impacts on every individual related such as parents and revitalize their conscience in order to and for resilience following resistance and accommodation. Most people try to behave using their ability to navigate during this period of hardship on psychological, social, cultural and physical resources. They negotiate resources in a meaningful way to the advantage of person or group. In conclusion, conscience becomes cultural resilience triggered by pembelajaran jarak jauh during pandemic of Covid-19 in Indonesia. Human consciousness upon conscience appear to sustain culturally after experiencing exaggerated and overwhelming feeling of being lockdown and sense being in cage beside problems in shifting behavior.
\end{abstract}

\section{Introduction}

Pembelajaran jarak jauh (for the rest using: distance learning) has been applied pervasively in academic and educational institutions all over Indonesia during the Covid-19 pandemic. It has been one of the goals in Sustainable Development Goal, founded about two decades ago. Pandemic of Covid-19 is positioning human life in this global world into borders social, cultural, economic, political, and nowadays it relates to technology [10] [32]. This reflective comes out from an indicator of distance learning spontaneously and abruptly using ICT being performed globally without instruction from global institutions intently conducted by all levels of education to avoid the prevalence of pandemic Covid-19[10] [33] [34] [35]. The event of distance learning spontaneously conducted globally began in the middle of semester learning, thus places human beings all over the world into the threshold. This condition

* Corresponding author: lawanda62@yahoo.com 
triggers issues and problems of human behavior in Indonesia beyond youth and seniors, kids and parents, etc. The events currently happen, reminding us people all over the world to behave about borders. Borders are reflected clearly when human beings in the condition of the threshold. This paper is an argument to counter-arguments concerning the events happening today, such as new normal, new culture, etc. Hopefully, it would contribute to theoretical and practical outline for human lives [1].

Pandemic of Covid-19 enforces ICT and the internet, to become significant to support human lives, such as distance learning. Learning used to be in the class meeting was viewed as the ideal in the pandemic Covid-19 event shifting to the online meeting in demand. Online learning used to be reluctantly accepted and neglected [20] [22]. Today online learning virtually becomes intently and conditionally in demand to perform [14]. Indeed, pandemic Covid-19 has not been controlled in Indonesia to be the cause of online distance learning as the only option to be conducted nowadays [27] [15].

Virtual distance learning performed encouragingly in Indonesia by majority forms something before merely imagination becomes the image of ideal learning [7]. Virtual meetings in distance learning enforce us all as the image of the ideal for learning by individual selves and authorities' power [19]. Policymakers try hard in many ways to encourage people to use distance learning by massive and extensive announcements addressing policies, regulations, and strategies wishing the process would reach learning goals. These regulations also apply for employees and employers of government and enterprises to perform a new work style from home. It might not be something new for people who have done it to comply with their jobs, but most people find it a new way of life. It is the blessing in disguise for ICT to boost itself by the power of nature. This kind of new style of meeting and gathering using variety of applications provided by ICT providers widely spread on variety of age groups not only kids in school age groups and students in higher education.

While all these uses of ICT applications have become important, how do students in schools and higher education accept and deal with this way of distance learning suddenly, excluding distance learning school and university students? Distance learning tries to understand how digital writing can be different from linear writing for print and to train his students in a new form of digital representation [24]. It becomes tyranny and pervasive at the same time. Higher education students may be assumed more easily adaptable with this kind of environment even though they need more effort to adjust with their lifestyle in using their applications from leisure entertainment and social interaction functions shifting in to more seriously focus on formal learning situation which used to be performed in the face to face class meeting [23]. School students seem to have got used to applications too. Somehow, they need more cost to spend on data purchase, which may be covered and altered by transportation fees. Adaptation becomes problems for most people in Indonesia, from ideals they used to get directly face to face meeting shifting to fabricated ideals in the image. The ideal of learning in traditional meanings are standards that society has made for itself. We assure ourselves that this distance learning during crisis event ideals is not dissolute since ideals are obsolete [14]. Students believe themselves a nation guided by ideals even though there still needs some minor students' efforts to get out of their reluctance, but this kind act is part of human behavior in common. Ideals are given by tradition it may not be reached but it is chosen as human guides.

Distance learning during the Covid-19 pandemic in 2020 is the most extreme postmodernism held that his environment made man. In this 2020 year, we try not to abandon the belief that our environment makes us. We also believe that we make our environments. We think we can fill our experience with newly into existing content. This event of technology has a good shadow for behaviors and human minds getting used of technology in living their everyday lives [6]. 
Everything used to be performed directly face to face in most customs as ideals shifted, becoming ideals as something in common was conducted using ICT [6]. Boorstin explains the situation as someone who seems to know a celebrity based on his knowledge. The axis of distance learning and Covid-19 pandemic condition places ICT holds as a source of life for every human being in this world, in particular, Indonesia. No one deliberately gives his life in this condition. Everyone is trying to survive by their ideas in this condition and situation [9]. Almost everything we see, hear and do attract us that the power is ours. Everyone makes their environment and fill the experience with whatever they please. Men in this universe seem to reflect on their conscience after positioning themselves as spectators of their acts in their lives. Man makes the actors and is the performers in this hedonism life.

The problem of ICT as the borders of distance learning during the Covid-19 pandemic in Indonesia reflects ideals and images of men; thus, the background of the event becomes the source of humanity [1]. Men make their environment and fill their experience by using ICT with its familiar characteristics. ICT and learning have been planned and encultured for the desirable effects of having it. However, the Covid-19 pandemic pushes aside men and the worlds into their center and also the margin of their lives. It is a deviant event occurring spontaneously in which its existence triggers the reflection of human conscience all over the world to do everyday life and activities from homes. In this situation, ICT is the source of life events of every human being in this universe. It becomes the image of the ideal that contains: expectation - reality; public-private; face to face - virtual to adapt and sustain in this world as represented in sustainable development goals. The problem is to show the image of the ideal in ICT actualized by the distance learning process as the way of life during the Covid-19 pandemic in Indonesia and worldwide.

The novelty about distance learning and the Covid-19 pandemic in Indonesia turns out to be the construction of conscience for individuals' resilience, and institutions respond to hardship in social, economic, political, and culture based on resistance accommodation of each self. It is not merely the issues of technology and medical notions, as many authors concern. Conscience amongst individuals and communities is a way for human beings in hardship time to resilience constructed from deconstruction, such as which based on adaptive coping and maladaptive coping [8]. It is a faculty of the mind that motivates us to act morally - or at least according to our most deeply held values [6]. Most say it is a form of intuition and uses emotion and is shaped by reason. Many are thought to be informed by objective morality, with divine, transcendental, or natural sources. Even in our society, where we ostensibly recognize the cultural and personal relativity of morality, conscience is granted a special status, with laws protecting persons' rights and others not to violate their consciences. So, conscience is private, subjective, and culturally relative, but carries legal and political weight. Conscience occurs during hardship becomes a way to resilience and adaption [11]. Hardship such a pandemic is viewed as a predicted natural bad luck in every culture and society related to individual physical substantive. Whereas in the context of distance learning it includes cultural, social meaning above technological issues. Technology in a socio-cultural context nurtures and develops in human culture and comes after deconstructing natural environment phenomena. In human life, technology plays a great deal for better living and support human development sustainability. The implementation of Sustainable Development Goals has been prepared enthusiast as a national global framework for the unpredictable crisis in health, development, and equity needs a system at every level. It provides a modality to a paradigm shift in policy and action to protect the planet and ensure all people in peace and to overcome poverty [22]. 


\section{Method}

The methodology performed is constructivism research. Constructivism research views reality is human product of intelligence interacting with experience in the real world. Therefore, this research includes human mental and activity to see men in the process of knowing reality [13]. The method of research was supposed to be done by field work by interview and observation as method of data collection. However, pandemic of Covid-19 happens to in the beginning of the process of interview preparation such as having connected with three students of fifth grade, a school teacher, and two parents of the mentioned music class students of Matahari primary school.

They are asked to express themselves about pembelajaran jarak jauh they are experiencing during pandemic Covid-19). The students of Matahari primary school is selected as they have used and experienced the distance learning once in a while before pandemic Covid-19 arise acquainted through the teacher. Therefore, data collection process is performed by online using applications such as online meeting room and text messenger in chat room, also telephone calls with the teacher. The interview is done sixth times in different days, and made as fieldnote and also the observation being done through virtual meeting using the application tool.

In the middle of interview process period of data gathering there appear a lack of capturing deep meaning and in observation limited to the appearance of the gesture and face movement. However, I try to capture every gesture and movement beside the statements being conveyed in every meeting we have in virtually. Therefore, data concerning understanding about pembelajaran jarak jauh performed by students, and faced by parents and teacher of music course. Students seem to be more enjoying having more time and space playing time between course of music class.

The teacher tries harder to motivate and stimulate students to be more prepared with their course and necessary instruments they supposed to play with. The teacher makes complaint several times of the parents not willingly helping their kids to get necessary instruments prepared for the course. Instead, they make statements of how the kids are uneasy to manage themselves for the class. At the beginning of study from home, the parents seem give favors to the kids. Along with time, the parents gradually seem to get exaggerated.

I manage to make transcription followed by categorization using operational concepts by the outline of resilience, conscience, and distance learning in the context of development sustainability. Meanings are drawn after data analysis then interpretations constructed. The field note is classified and categorized in accordance to the topic and issues as the problem is complex. The transcription then is analyzed to get meanings and essential issue occur behind every event that is conscience.

The significant of the finding that conscience is essential as quality of human and humanity in the life of human beings. Man keeps trying to sustain in this life which sometime crisis come to threaten and fear them but also there are also blessings at the same time. Documents of reports and articles from mass media also become data concerning school distance learning, Covid-19 pandemic, and government regulations related to those two events. Dataset flourishes the interpretation of conscience which revitalizes during Covid-19 in Indonesia. Pembelajaran jarak jauh becomes the entry point of this discussion. 


\section{Results and discussion}

\subsection{To navigate within borders amidst the shifting process}

The assumption is that societies all over the world now appealingly perform distance learning shifting from learning in physical class during Covid-19 pandemic, it is two distinct remain separate from each other. A cultural border is expected to form between them. A border is not a neutral demarcation line. It is a symbol of power that imposes inclusion and exclusion. The more privileged dominant, hegemony side will actively control the border to keep border-crossers out. Erickson accentuated the political nature of a border is a social construct that is political in origin [12]. Across a border power is exercised, as in the political border between two nations (p. 42). It is clearly distinct to a cultural boundary refers to the presence of some kind of cultural differences as characteristic of all human societies, traditional as well as modern.

A cultural border connotes a barrier that a more powerful side constructs to guard its own political power, cultural knowledge and privileges. Issue of ideal appears on majority of men in Indonesia as ideal regarded to be more ecstatic, optimistic and glowing, distinguishing itself from the real culture, which is the actual picture of the society. The gap between the ideal and real culture is wide. While ideal culture involves an idealized and resolute value system that controls perfect behavior, real culture involves a value system which is adaptable and serves as a set of preferred guidelines. The border between ideal and real culture conscience. Conscience as the practical reason when applying moral convictions to a situation [28]. Conscience may be gain through daily contemplation and meditation combined with selfless service to others. Digital consciousness is the advent of a post materialist theory of everything [11].

The gap of these two on men is mediated by image. Image has been used by everyone seems familiar with the word. Distance learning during Covid-19 replacing in class learning is assumed to shift the ideal. The shifting happens as the image truth on ICT succeed to be a guide for majority of people to make a choice in ways of learning and life. It is not ambitious if we say that ICT or life style of ICT becoming a best seller commodity during Covid-19 in this universe. Because of the situation, the image also goes with community, enterprise, nation, leader, and ourselves, also becoming the image. These images are continuously and wide spread being used in everyday life, and repeated in academic meeting by professors, employees/employers, and people at home with their family members. These words become familiar which actually are images because of extensively ICT has diffused in every human being everyday life, that makes the images of those become real because they become familiar.

Today, everybody can create his own experience, using the facilities of ICT. We may get the faith to the end that we can measure our lives. Each of us now keeps trying to make the ideal of our own self. It may be said that we are now reaching the ultimate of our expectation as man. Now, we are no more talking about ideal instead we are now talking about a sum of ideals. The statements of teacher and parents,

"All the courses are conducted by online because of the protocol of pandemic. It is really more tiring job rather than usual courses in the class at school concerning the issue dealing with kids. Even though, e-learning has been performed instantly as optional in some courses occasionally before the pandemic, full-time e-learning need more efforts in the condition we have to deal with ourselves. Kids have getting used with using application as provided by school but we need more to shifting the focus now on our kids full time." 
All these times, man use to say that God creates man using his own image. Today, man may invert that metaphor to his by the use of sophisticated ICT. The order of nature and the order of God works in hand naturally to this universe. God and man are a flexible world. The relation between the two produces what it is called by values. The use of ICT extensively and massively around the world during pandemic Covid-19, men have succeeded emptying the word of values. Students says that "they have been getting used by using applications. They have made application as parts of their life but to do learning all day through and everyday using online learning put them in more flexible way and more option in their conduct."

This situation happens when men thrust traditional meaning of values in the context of ethic. Values mean customs, institutions etc, relate to human groups, ethnics, etc. values have been sounded continuously in order to guide men towards certain standard made by the society. In fact, today, during Covid-19 pandemic, those ideals have been left behind. However, there a lot of people still hold values as their life guide as they claim they are most civilized.

Ideal is like a star in the sky. Men have never enabled to reach out. Men accept ideal as the life guide to reach destiny. Men also realize that they are created by environment, but now men believe that environment can be created by men. This contradiction drives men to deal with things and a source of life event such as creating super hero. Everything in this world today are nothing original, but image of images which are created by men. Men believe that experience can be fulfil with contain using ICT. Today, everything that men see, do, hear, are the power of men. Today, life becomes the audience watching men as players are playing a play.

\subsection{The negotiation upon the characteristics of god image adhere on information communication and technology}

Distance learning during Covid-19 pandemic retreat people behavior to be more focus on interaction with the core family and kin, stay at and work from home, even make new acquaintances all over the world crossing borders without meeting face to face. Covid-19 pandemic and ICT usage work a synergy way to create a life [26]. Individuals all over the world are urged and conditioned to practice their life as usual life with usual behavior but there are obstacles concerning activities should be performed in public meeting. Anyhow, in spite obstacles viewed on the other side of the coin, may have opportunities for men to retreat and reflect themselves. People begin to redefine themselves and make a reflection upon their life and life style before the pandemic of Covid-19 wide spread arouse. Image technologies prominent in today's communications technologies are acidic and to and inherent in traditional cultures [18].

Before the pandemic Covid-19, learning process seems to be teachers and school duty absolutely, since parents are mostly occupied with their own job as members of community or employers of an office or may be directors of an enterprise or government office. The era of economic capitalist supports the democratic country as well as the need of capital arising in family life [2]. Parents are encouraged to work to fulfil the needs of family standard. On the opposite side, shopping malls are facilitated to be the channel for every members of family throw their spending. Malls on the other hand, can be viewed as the representation of consumer nation in spite of producer nation. There is the process of negotiation between resistance and accommodation towards values in real life before and the image of real-life facing e-learning during pandemic Covid-19. This is based on adaptive coping and mal adaptive coping by human in experiencing e-learning [6]. This situation gives impact to the process of online learning at home by school kids who needs more support and guide which used they get from teachers at school. Parent seem to get exhausted and overwhelmed in supporting their kids in online learning process at home. The statement of parents, 
"Distance learning ...ough...It makes no sense. We, parents, mothers, become more intense and preoccupied with our kids beside all the job, household stuff that we have to consider. (complaining). The kids become late getting up for school, we have to wake them up ...they don't get prepared unless we make them to...."

Teachers complain that students neglect the process of learning in virtual meeting using an application from certain option provider. The statement of the teacher,

"Students are getting lazier to get every stuff needed being prepared. Parents are getting tired accompanying their kids all the time during courses. Parents seem to complain on their kids but in fact it is their responsibility. Parents could not just rely everything on the teacher. There is kid that mourning about the music instrument unable to find; there is one saying the instrument left in the friend's house, etc. I need to be more supportive and also more determined facing various behavior of the kids during this period of full-time e-learning. Those parents should help the kids while they kept complaining of themselves. How come parents would not want to help their own kids in e-learning ...(sighing)..."

Some kids still have the spirit of learning as usual but some prefer to take it for granted. Anyhow, parents seem uncoordinated to manage the process of learning for their kids, from preparation until summarize [12]. It assumes because in a sudden they have to do works that are said beyond expectation learning by online. This situation has been going since the development of ICT in universities. Universities enforced to produce production that can be measured in order to get positioning the status and level in competitive global competition [23].

The notion of work from home and stay at home put and give many people the feeling of trapped and being in the cage [10] [17]. While before this pandemic they use and often getting out of the house for leisure and pleasure rather to get it from being at home. Malls and restaurants attract and form standard and level of life style. Social status defined by malls and restaurants and hotels visited [30]. Most gatherings were performed in malls which shifting gatherings used to be at home. Before many luxurious and fancy malls being built, family time is at home in the dining table and living room. This traditional habit replaced by modern habit of family spend most of the time outside the home by eating out or shopping. It is not tendentious to say that Indonesian people in urbans and rural have been influenced and infused by hedonism life style. People do their living and behaving in ways that mean you get as much pleasure out of life as possible, according to the belief that most important thing in life is to enjoy yourself.

Protocol of Covid-19 pandemic globally apply including Indonesia government. The pandemic and its protocol turn the life, government policy in politic, economic, social, cultural seemed turning upside down if we see it from the point of view of pandemic [31]. However, when you come to see this condition as ethic, the world, nature, and universe make men to turn back and revitalize conscience naturally. It seems the way of universe to govern itself and manage human being who have lost control in managing environment which actually as the source of their living. The movement of stay at home may be a way to hold men up from spending more leisure and hedonism life outside their habitus. This event retreats men to come back and know their selves by conscience [5]. ICT creates an image of life source event in making human life sustainable and enable to continue sustainable development movement.

Information Communication and Technology has the power for men enable to create and to form expected environment, and then to fill the environment with expected experience, including creating God. God for men whom believe in him can be viewed as a life source event which bear the characteristics of God familiar to men. God is not exist spontaneously or not even creating himself. God exists by men planning and internalizing continuously to others. God is created primarily to fulfil hopes and be the place for men to report about life. God gives impact to the life of his believers. It is rather absurd to say but on the other hand 
it is reasonable to view God may be regarded as internet and applications which has been used by most men in this world and Indonesia to fulfil each individual need to watch. The power of internet and its applications can be measured through reports conducted by user individuals, and the report about frequency of user individual accesses. The relation between God and reality underlying works ambiguously. This situation triggers us to ask question what has God done to us men?

There are people worries about God credibility being disruptive by certain groups. On the other hand, men create God intently with the believe that God fulfil his own need. God is likely as great celebrity being admired and begged for the mercies by men. In the sensible mind, God is provided by men in order to fulfil the emptiness that sensed by men. God becomes the greater of the great. This then makes people that think that God is not a fact of nature but a fabricated usage for men whom are afraid of God. Men believe in the greatness of God that God creates himself. There are people assume that God is not power because God creation is by himself in the image of believers. Information Communication Technology has the characteristic of creation but it is in fact created by men. Men whom create ICT and master the function and mechanism of ICT may govern the image of ideal because they manage the creation of men and the world. Even though, there are people become the believers of ICT now adays rising up in number. This passing two months, there are webinars using the title that has an option meaning such digital or die. The statements contain deep structure of men nowadays that ICT is not an option but it conveys the image to sustain the men life. It is just like the image and the ideal of Sustainable Development Goals adopted by all member states of United Nation in 2015, the period 2016-2030 to address the overwhelming empirical and scientific evidence that the world needs radically more sustainable approach [22].

In sum, men as human beings have conscience use ICT extensively because Covid-19 pandemic occur and corner men to no option to sustain their life. The process of distance learning during the pandemic is showing us about the process of ritual in human life in cycle giving the impact to retreat and reveal their conscience. When it comes to ethic, conscience acts as the image of the ideal to manage and treat environment, social and physical [3]. Conscience control behavior of men such as hedonism and also crisis. Conscience is the sustainable image and ideal that become the foundation and guide for men to their acts, conduct, and behave towards himself and his environment to reach sustainability development.

The challenge that most of us have to take in three dimensions system that include the ministry of primary and secondary education, parents/students/teachers and researchers. Researchers need to participate more in giving the solution to the government in this case the ministry of education in primary, secondary education to clarify the e-learning in the ways student way of thinking and feel in order to ease the shifting process, and to nurture the image values from the real life to enculture in their e-learning experience. The ministry of education and the researchers both provide talk shows or seminars to parents as the way to support their resilience and development sustainability personally through their kid schools as providers. This way out to nurture every one conscience and resilience in three dimensions system may be the solution based on this topic of paper.

\section{Conclusion}

For most people in their experience, distance learning (Pembelajaran Jarak Jauh), and also Covid-19 pandemic are viewed as a life source events positioned at border grits. There is resistance and accommodation at the same time on kids, parents and even the teacher occur during the experience. It has the meaning of resilience to live and or/ die back to human ego is conscience. Conscience is the core of individual ego to resist and accommodate by 
navigating his/her life in this world which include most of human aspects such political, social, economic, and religious belief. However, borders push men in all over the world to revitalize human conscience in their whole lives when there is an exaggerated source life in a sudden and emergent need. The meaningful immense event operates and revitalize conscience in men because of threats, fears and worries. The conscience becomes significant since it was in the state of being secluded while hedonism behaviour overload human minds and passions. Conscience revitalizes when an event intervening in the life of human being trespassing borders which supposed to be watched out and nurture in order to avoid human beings plunging in the threshold. Conscience fills the soul and physical body of human beings from the beginning till the end.

The two meaningful life source events reflect that men live in the world of facts and at the same time also living in the world of image from the world of values. The image gives its fact to men in this world by ICT which becomes the hand of God for men to climb up out from threshold. Information Communication and Technology then becomes the ideal of the image. Image works in fabricated way, believable, even though passively, vaguely, and ambiguous. The meaning of fabricated in this context it tries to convey the meanings that image is something coming out of the plan especially created by particular people as a particular intent to impress others. The movement perform reciprocally to enhance impressive and clean impression.

Image in this context means that human beings acknowledge a distinction between what we see and what real is. However, we express our own preferences on what is going to be seen. Image created by the use of ICT during the events of distance learning in the midst of pandemic Covid-19 ensures us about the definition of image is the personality of public which has the characteristic of virtual. It differs to individual characteristic which is implicit. Public lives naturally along with image, and interest and opinion to development sustainability.

Image then becomes believable. Image becomes a way to reach virtues shown in the picture of distance learning during pandemic Covid-19 objectively and subjectively. The assumption that image becomes important thing in the time of cultural social process. And, image too, becomes like an enterprise as enterprise is an image. The image becomes perfect and also becomes the pattern of life which give satisfaction to each individual, it may happen as the image is formed as virtual, concrete, and simple. After all, citing Boorstin statements this paper is to reminding us about the stuff in every aspect between men and reality and ICT, that is conscience as ICT now become the real reality for human lives. As e-learning becomes the core of SDGs then conscience as the core human existence live the experience of human life in equity.

\section{Acknowledgements}

Herewith, I thank students of SD Matahari, Teacher of Miss Aisyah, and parents that have provided supports as the source of knowledge to be reserach data collection.

\section{References}

1. S. Anderson, Review: Brian Massumi, Architecture of the unforeseen: Essays on the $\begin{array}{llllll}\text { occurrent arts. Journal of Visual Culture, 19, } 1 & \text { (2020) }\end{array}$ https://doi.org/10.1177/1470412920904642

2. S. R. Apresian, Responding to the COVID-19 Outbreak in Indonesia: Lessons from European Countries and South Korea, Jurnal Ilmiah Hubungan Internasional, (2020) https://doi.org/10.26593/jihi.v0i0.3868.53-57 
3. S. H. Awad, The social life of image, Visual Studies, 35, 1 28-39 (2020) https://doi.org/10.1080/1472586X.2020.1726206

4. G. Basilaia, D. Kvavadze, Transition to online education in schools during SARS-COV2 Corona virus (COVID-19) PANDEMIC in Georgia. Pedagogical Res. 5 4, 1-9 (2020) https://doi.org/10.29333/pr/7937

5. S. Bhattacharay, Peer-reviewed Images: Image Consuming Selves as Visual Commodities. Society and Culture in South Asia, 51 (2019) https://doi.org/10.1177/2393861718787873

6. D. J. Boorstin, The image: A guide to pseudo-events in America (Atheneum, New York, 1987)

7. H. S. Budim J. S. M. Ludjen, A. C. Aula, F. A. Prathama, R. Maulana, L. A. H. Siswoyo, A. S. Prohantono, Distance Learning (DL) strategies to fight coronavirus (COVID-19) pandemic at higher education in Indonesia. International Journal of Psychosocial Rehabilitation, 247 (2020) https://doi.org/10.37200/IJPR/V24I7/PR270859

8. C. S. Clauss Ehlers, Sociocultural factors, resilience, and coping: Support for culturally sensitive measure of resilience. Journal of Applied Developmental Psychology, 293197 212 (2008) https://doi.org/10.1016/j.appdev.2008.02.004

9. Y. R. Damuri, F. B. Hirawan, Mengukur Dampak COVID-19 pada Pertumbuhan Ekonomi dan Perdagangan Indonesia 2020, CSIS Commentaries Jakarta, (2020).

10. Djalante, Riyanti and Lassa, Jonatan A. Review and analysis of current responses to Covid-19, Indonesia in Progress in Disaster Science 6 (2020).

11. Elvidge, Jim. Digital consciousness: A transformative vision. United Kingdom: Iff Books (2019)

12. Erickson, F. Culture in society and in educational practice. J. A. Banks and C. A. M. Banks (Eds.), Multicultural education: Issues and perspectives, 32-60. Boston, MA: Allyn and Bacon (1997).

13. Eze, S.C. et.al. The utilisation of e-learning facilities in the educational delivery system of Nigeria: a study of M-University. International Journal of Educational Technology in Higher Education, 15, 1), 34 (2018)

14. Hilbert, T. S.; Renkl, A. "Learning how to Learn by Concept Mapping: A WorkedExample Effect". Paper Presentation at the 12th Biennial Conference EARLI 2007 in Budapest, Hungary (2007).

15. https://www.datadikdasmen.com/2020/3/se-mendikbud-no-4-tahun-2020-html, (2020)

16. https: //guruberbagi.kemdikbud.go.id/artikel/pembelajaran-berbasis=daring

17. https:// guruberbagi.kemdikbud.go.id/artikel/refleksi-pembelajaran-daring

18. https://www.thejakartapost.com/academia/2020/05/01/covid-19-children-must-keeplearning-despite-crisis.html, (2020)

19. Ihde, Don. Image technologies and traditional culture. Inquiry, 35, 3-4 (1992).

20. Kleeman, Mariska and Daalman, Serena. Picture perfect: The direct effect of manipulated Instagram photos on body image in adolescent girls. Media Psychology, 21, 1 (2018).

21. Mahtani KR, et.al. What is the evidence for social distancing during global pandemics? A rapid summary of current knowledge [Internet]. Oxford, UK: Oxford COVID-19

Evidence Service [updated 2020 Mar 19; cited 2020 Mar 31]. (2020)

https://www.cebm.net/what-is-the-evidence-for-social-distancing-during-globalpandemics-a-rapid-summary-of-current-knowledge/.

22. Moe, S and Naing, D.K.S. Role of e-learning facilities on student's learning: a literature review, ICERI2012 Proceeding, 3941-3948, (2012). 
23. Morton, S and Pencheon, D. Sustainable Development Goals (SDGs) and their Implementation: a National Global Framework for Health, Development and Equity needs a system approach at every level. British Medical Bulletin, 124, 1, 1-10 (2017).

24. Muhyiddin and Wardhana, Dharendra. Covid-19 outbreak and development planning in Indonesia, The Indonesia Journal of Development Planning, 4, 1 (2020).

25. Mulyanti, Budi and Purnama, Wawan. University in vocational high school during Covid-19 pandemic in West Java Province Indonesia. Indonesian Journal of Science and Technology, 5, 2, 96-107, (2020).

26. O'Gorman, Marcel. E-crit: Digital media, critical theory, and the humanities. Toronto: University of Toronto Press (2007).

27. Putra PMS. Menko PMK: Jokowi setujui aturan karantina wilayah di tingkat daerah. Liputan 6 [Internet]. 2020 Mar 30 [cited 2020 Mar 31]. Available from: https://www.liputan6.com/news/read/4214913/menko-pmk-jokowi-setujui-aturankarantina-wilayah-di-tingkat-daerah.(2020)

28. Setiwati, Siti and Azwar, Muhammad Khifzon. Covid 19 and Indonesia. Acta Medica Indonesiana, Vol. 52, http://www.actamedindones.org/index.php/ijim/issue/view/76. (2020)

29. Setiawan, Adib Rifqi. Scientific literacy worksheets for distance learning in the topic of Coronavirus 2019 (COVID-19). Reading Academic Articles 2. (2020).

30. Singer, Peter. Democracy and disobedient. Oxford: Clarendon (1992).

31. Song, Junho, et.al. "Is a picture really worth a thousand words?": A case study on classifying user attributes on Instagram. PLOS ONE (2018).

32. Susilawati, et.al. Impact of Covid 19's pandemic on the Economy of Indonesia in BIRCIJournal (2020).

33. Viner, R.M. et.al. School closure and management practices during corona virus outbreak including Covid 19 : A rapid systematic review. The lancet child and adolescent health 4(5), 397-404, (2020).

34. World Health Organization. Coronavirus disease (COVID-19) situation dashboard [Internet]. Geneva, CH: World Health Organizationcited 2020 Mar 31]. Available from: https://experience.arcgis.com/experience/685d0ace521648f8a5beeee1b9125cd.(2020a)

35. World Health Organization. Key messages and actions for COVID-19 Prevention and Control in Schools. Geneva: WHO, March (2020b).

36. www.unicef.org/.../learning-home-during-covid-19-pandemic

37. www.weforum.org/agenda/2020/04/coronavirus-education. 